\title{
Path Selection of Xi'an Free Trade Area Construction under the Strategy of \\ Silk Road Economic Belt
}

\author{
Chen Weifeng \\ Xi'an Liberal arts College, \\ Xi'an, Shaanxi, 710065
}

Abstract - From the present situation of worldwide free-trade area and the new trend of reform and opening in China after 18 of the fifth plenary session, you can see that in domestic, the construction and development of free-trade area, taking regional core city as center,is economy transformation means under new normal economic environment, and new clues to improve the level of reform and opening. The establishments of free trade Area in Shanghai, Guangdong, Tianjin, Fujian provided references for establishing a free trade area of $x i$ 'an under the background of the silk road economic belt construction. This article firstly analyzes the present domestic and foreign research situation and development trend; and then put forward the necessity of building Xi'an free trade area. Then discusses the Xi'an Silk Road economic belt free trade area construction strategy. Finally, in combination with the practical situation of Xi'an, it proposes path selection of $X i$ 'an free trade area construction under the strategy of Silk Road economic belt.

Keywords- Silk Road Economic Belt, Xi'an Free Trade Area, Path Selection

\section{INTRODUCTION}

The raise of strategic concept of "silk road economic belt", provides absolutely new ideas and perspectives to city development, taking
Xi'an city, in Shaanxi province as the center. Actively building free trade area, taking Xi 'an as the center, covering and radiating surrounding city Baoji, Xianyang, Tongchuan, Weinan, etc., already become the implementation of the third plenary session of the eighteenth ", and inevitable requirement for accelerate the construction of free trade area and the inland opening-up.

\subsection{The domestic research status}

Domestic scholars studied on issues related to "silk road economic belt". Free trade area, mainly distributed in two aspects, "silk road economic belt" and Shanghai free trade area.

Essays and writings about silk road economic belt was typical, such as "Silk Road Economic Belt: Beyond The Connotation Of The Geographic Space Recognition And Its Contemporary Interpretation" written by WeiLing,etc., "Silk Road Economic Belt ": Strategic Connotation, Orientation And Implementation Way" written by Hu'angang,etc.,"Silk Road Economic Belt: Advantage Industrial Spatial Differences And Industrial Spatial Layout Strategy Research" written by Guoaijun, and so on.

Chinese scholars' researches on free trade area, Wu Si (2013) argues that the four big problems test the free trade zone in Shanghai. Firstly, it is problem of land supply. Secondly, it is administrative system. Thirdly, it is barriers to entry. Finally, it is regional siphon. Huang Xinhan (2013) argues that great significance of the 
establishment of Shanghai free trade zone is a major measure of the reform of open reversed transmission. Mainly displays in three aspects. One is open to promote the improvement of the domestic market economic system, improve the enterprise innovation ability, reversed transmission economic system reform. The second is open to speed up the transformation of government functions, simplify examination and approval procedures, reversed transmission regulation reform. Thirdly, open to promote administrative streamline, reversed transmission administrative system reform.

\subsection{Aboard research status}

Compared with the domestic research status, foreign scholars mainly concentrated on the study focus on hot topic about the development of free trade area and Silk Road economic belt. As for transit feeder, combination, international trade and industry export processing, bonded storage types such as free trade area of the study. The American scholar Mostrous and others introduced Silk Road economic and other elements into academic research. For example, The silk road to riches :How you can profit by investing in Asia New found prosperity, The limits of cooperation: central Asia by Kathleen Collins,Afghanistan,and the new silk road; China' s neighbors by Dezan: Whois influencing china and who china is influencing in the new emerging Asia.

\subsection{Research development trend}

Because of Shaanxi province is located in the core area of "silk road economic belt", and Xi 'an is the engine of economic development in Shanxi Province and window opening to the outside, so build free trade area of $x i$ 'an under the background of "silk road economic belt" has very important macroscopic and microscopic significance to many major problems such as international metropolis construction in Xi'an, the Guanzhong - Tianshui economic zone construction.

\section{The necessity of building Xi'an free trade area.}

2.1 Is conducive to enhance the international metropolis construction level of Xi'an and organic fusion strategy of "area". As the starting point of the "silk road economic belt" $\mathrm{Xi}$ 'an has become an important hub of the silk road economic belt with the advantages of geographic location and relevant national policies radiation surrounding areas the Guanzhong urban agglomeration and the development of the "west triangle" economic zone, can free trade area of urban construction, and an provide important support and guarantee for the construction international metropolis of Xi'an.

\subsection{Is helpful to reduce the cost of international} regional cooperation. To establish a free trade area in Xi'an, will get through China Eastern Midwest trade channels, improve the using efficiency of production factors, to provide strategic support for the silk road economic belt construction, promote the inland opening-up proceed, play radiation and agglomeration effect on countries and regions along the silk road economic belt, promote cross-regional cooperation in worldwide, particularly with five central Asian countries and the organic connection of central Europe.

\subsection{Construction and development of $\mathrm{Xi}$ 'an international inland port provides necessary material base for the construction of the free trade area.}

Set up the silk road economic belt free trade area in Xi'an, plays the advantages of $\mathrm{Xi}$ 'an comprehensive bonded zones and export 
processing zone, on the basis of gradually expanding the scope of the trade zone, radiation the guanzhong urban agglomeration, vigorously develop high and new technology industry, tourism, the equipment manufacturing industry, modern service industry, such as the new industry.

\section{Xi 'an silk road economic belt free trade area construction strategy}

\subsection{The analysis of the of $\mathrm{Xi}$ 'an conditions to establish free trade area}

As the capital of Shaanxi, the northwest region's largest city, Xi'an is the starting point of the Silk Road, world-class tourist city, the geographical condition is superior. And is equipped with modern transportation network with modern three-dimensional. Xianyang international airport in Xi'an is one of the six major airports in China, $\mathrm{Xi}$ 'an is the largest railway hub in western region in China, is an important node of Eurasia land bridge. Highly developed modern transport network is built, $\mathrm{Xi}$ 'an and countries along the Silk Road, and the area in central China, southwest, western hinterland contact more convenient, Xi'an's location advantage is more prominent.

\subsection{Function orientation and development direction of $\mathrm{Xi}$ 'an inland free trade area}

Overall, Shanghai, Guangdong, Tianjin, Fujian free trade area belong to the coastal free trade zone, free trade area to be built in $\mathrm{Xi}$ 'an belongs to continental fta, its position should be different from other free trade areas have already been approved. Xi'an free trade area should be accurate positioned, strive to build "the silk road economic belt" continental test free trade zone, driving the development of Shaanxi Guanzhong urban agglomeration, lead the northwest five provinces and Shaanxi-Chengdu-chongqing economic development of the west triangle economic zone, the radiation of the silk road economic belt along the urban and regional connectivity, coordinated development.

\section{Path selection of Xi'an silk road economic belt free trade area}

\subsection{System innovation in the field of trade and investment}

Draw lessons from four free trade zones in Shanghai, Guangdong, Tianjin, Fujian experience, $\mathrm{Xi}$ 'an should carry on system innovation in trade, investment, to develop Xi'an before free trade area of the access, national treatment and negative list policy, gradually relax investment restrictions in Xi'an for investors from home and abroad, widely attract foreign capital. Dealing with foreign investment projects by the authorization to register system, convenient and foreign investment, reduces investment barriers to entry, provide convenience for foreign investment.

\subsection{Enhance the level of $\mathrm{Xi}$ 'an open, based on "silk road economic belt"}

$\mathrm{Xi}$ 'an port equipped with platform is a major advantage of Xi'an. Xi'an no border, not near sea, but there are $\mathrm{Xi}$ 'an international port district, the nation's largest inland port, also has two fully functional comprehensive bonded zones and export processing zone, and has certain basis and experience in under special customs supervision and open to the public policy innovation, has the ability to have a convenient conditions for opening to the outside places along the silk road of the port logistics service, the construction of $\mathrm{Xi}$ 'an silk road economic belt free trade area, can further enhance the radiation in the silk road economic belt construction in Xi'an, drive, service, support, make it become the connecting Europe, linking the west hub, thus achieve to link, in line with the effect of 
implementation of the silk road economic belt involves eight between urban agglomeration, and the silk road economic belt and the Yangtze river economic belt and coastal economic belt between the mutual exchange, collaborative development.

\subsection{Deep financial reform and build regional financial center in Xi'an}

According to $\mathrm{Xi}$ 'an finance office's statistics, in 2015, the added value of $\mathrm{Xi}$ 'an finance topped 60 billion yuan, more than $10 \%$ of GDP, more than Chongqing, in the super city in western municipality directly under the central government, its financial industry pillar industry status is further consolidated. Currently, there are more than 130 all kinds of financial institutions in $\mathrm{Xi}$ 'an, including 41 Banks, securities and 26 futures institutions, 51 insurance institutions, 3 trust companies, 4 financial companies, 1 auto financing company, 69 financing guarantee companies, total financial institutions assets of nearly 3 trillion yuan, the financial indexes in the northwest city ranks first. With the construction of $\mathrm{Xi}$ 'an international metropolis and cooperation with countries along the Silk Road economic belt and the area of extensive, $\mathrm{Xi}$ 'an deepen financial reform, the construction of regional financial center is particularly urgent, it also provides the free trade area of the construction and development effectively.

\subsection{Transform government function under the condition of system innovation}

The transformation of the government function is particularly important when construct free trade area. To build free trade area in Xi'an, should focus on the change of government function. According to the concept of free trade area, the construction of free trade area need to transform the government functions in accordance with the requirements. The government should further liberalization in market access, trade to goal, "within the territory of the commissioner of" supervision afterwards.

\section{CONCLUSIONS}

Demanded that the government must be a limited government, responsible government. In related fields the government should be of both tube and pipe less in place, the government should be the efficiency government, service-oriented government, and provide efficient, high quality service to the main body of market. At the same time, the Xi'an government should follow the example of Shanghai, strengthen their own reform and process re-engineering, optimization for the services of market and enterprise. Xi'an government should also be in cultivating the social credit system, improve the information sharing and comprehensive law enforcement system, encourage social forces to participate in market regulation, etc. to develop a series of rules and regulations and strictly abide by, as the matter later regulation to study the key areas and crucial links, such as worn.

\section{Acknowledgment}

Fund project: Specialized research plan by Shaanxi province department of education about Feasibility Research of constructing Guanzhong urban agglomeration free trade area under the strategy of Silk Road economic belt. (Grant NO. 15JK2141).

\section{References}

[1] Yang Weixia,Relying on International Dry Port for Constructing Free Trade Area Development Plan of Xi'an, Journal of Commercial Economics,vol.9, 2015.

[2] Li Xiaojie, Construction of Xi'an FTA under 
"Silk Road Economic Belt" Market Modernization, vol.9, 2015.

[3] Feng Zongxian, Foreign Free Economic Zone Development Situation and China's Countermeasures, Economic Review, vol.10,
2015.

[4] Zhang Lina,Enlightenment for Experience of World Free Trade Zone in Xi'an Establish Free Trade Test Area, Oriental Enterprise Culture, vol.11, 2014 